Philosophy and Progress: Vols. LXI-LXII, January-June, July-December, 2017 ISSN 1607-2278 (Print), DOI : https://doi.org/10.3329/pp.v61i1-2.44203

\section{SOME PROBLEMS OF BUSINESS ETHICS: ISLAMIC POINT OF VIEW}

\author{
Abul Khayr Md. Yunus*
}

\begin{abstract}
Business ethics is one of the important branches of applied ethics. Many thinkers including ethicists, economists, academicians and philosophers have tried to explore necessary principles, standards, rules and regulations for business-related issues. Islam, a major religion of the world, has prescribed, from its very inception, necessary rules and principles for every aspect of life including business and commerce-related dealings. This paper explores Islamic concepts of business, its principles, rules and regulations. From the Islamic point of view, this paper shows that business is not merely a job of profit-making, but also an ibadah (worship). Moreover, it claims that Islamic business ethics is not only concerned with moral soundness of business persons, but also closely connected with the salvation of man.
\end{abstract}

Key words: Business, Islamic ethics, halal (lawful) earning, haram (unlawful) earning, consumer protection, corporate social responsibility.

\footnotetext{
*Associate Professor, Department of Philosophy, University of Dhaka. E-mail: yunusakm@gmail.com
}

\section{Introduction}

Business has been emerged from the necessity of mankind. In primitive society, men fulfilled their necessities through mutual exchange of commodities. One had a kind of commodity while others had different kinds of commodities. So, they exchanged them with each other which is well-known as Barter system. However, it was not effective for long. It was also not possible to exchange goods for goods because of gradual increase of man's diverse needs and demands. Human beings started to produce goods for making profits instead of exchanging goods. So, they introduced some measurement such as the rare snail, the oyster, the stone and so forth for exchange of goods. But it was not also effective for long. Later metallic coins, bank-notes etc. were used for the exchange of goods. In this way, business activities gradually have been advanced.

In business, there are different categories of people one has to respond to: shareholders, creditors, customers and clients, employees, dealers, vendors, suppliers, government and society as well as international companies and organisations. So, business persons should abide by some rules and regulations for their dealings. Herein the question of ethics is involved in business. It needs principles, ideal codes of conduct, rules and regulations. In this regard, a discipline named 'business ethics' was established by ethicists, moralists, economists, academicians and philosophers. It has definite subject-matter, principles, standards and methodology. Islam, as one of the major religions of the world, has its own way of dealing with the business-related issues. In this paper an attempt has been made to explore Islamic attitude, principles and rules and regulations regarding business. 


\section{Islamic attitude towards business}

According to Islamic belief, the earthly life of human being is transient while the life after death is permanent. In the life after death man will be rewarded or punished for his/her earthly deeds. For this reason, the life and activities of an individual in this world is not less important. So, a man has to take this world seriously. S/he has to take this world seriously for his livelihood and sustenance. One can't live without earning. Accordingly, an occupation is most vital one for human being. There are many occupations for earning, business is one of them. Islam has encouraged business and has given businessman a significant status.

Islam places great emphasis on business. There are many Quranic injunctions which have encouraged to engage in lawful trade and commerce. Al Quran vehemently prohibits to possess other's property by wrong means. Allah (SWT) said: "O ye who believe! Eat not up your property among yourselves in vanities: But let there be amongst you traffic and trade by mutual good-will." (Al Quran, 4:29, vide, 73:20, 35:12, 62:10, 30:46, 62:10-11) There are underlying wisdom in business which are:

a. Goods and services can be made available through business. One produces goods, but if one cannot distribute them to others, he/she will lose his interest in producing further, or he will be bound to destroy his products. Similarly, if a skilled person or a service provider (like, an advocate) does not get any client to extend his service, he will lose incentive in his profession. So, business can uphold the availability of goods and services.

b. Necessities of human beings are multi-dimensional. One cannot fulfill his all needs and requirements by his own efforts and capacity. S/He has to depend upon others. One can provide one kind of things or services and another can provide different kind of things and services. Thus one can meet another's necessities. That's why men are dependent on one another. This dependency can be met through business. So, without business human necessities cannot be met.

c. Business is a great source of income and gaining wealth. There are many lawful ways to earn money and livelihood, but business is of great worth. In business, man has to engage wholeheartedly. It needs physical and mental labours through which man's earning becomes more pure.

We should keep in mind that business cannot run without some principles, rules and regulations. Without rules and principles whimsicality and willfulness will be advanced in business. As a result, business will be a means of exploitation and businessman will make money by hook or crook; customers and clients will not be taken into consideration for their benefit. Eventually, the individual and society will be harmed and degraded by the whimsicality and willfulness of businessman. For the intelligible reason, business ethics has been advanced through ages. For the same reason, Islam has provided some standards, principles, rules and regulations for achieving wealth, means of production, distribution and auxiliaries related to business issues.

\section{Main purpose of business}

In early times, it was said that the business of business is business. That means, the only motto of business was to make profit. Nowadays, the idea of business has been changed. The idea of social responsibility has been conjoined profit- 
maximization amid continuing debates for and against the generation of profit in business. Some people think that making profits are the only business of business while others hold the view that business activity should engage more than mere profits. (vide, for details, Satris, 234-249) Undoubtedly, business is profit-oriented enterprise. But Islam significantly presents different implication by business. It refers business to latent purpose of human life. The life after death is final, permanent and eternal according to Islam. So, this worldly life is less important than life after death. A person wants to achieve final goal in his/her life hereafter through all activities in this worldly life. For this reason, earning livelihood or making profit only is not his/her main target through business. $\mathrm{S} / \mathrm{He}$ wants to earn livelihood and do business but s/he does not want to lose a little thing in life hereafter. That is why he loves Allah, the Almighty, and the akhirah (the life after death) more than his business.

Giving priority and supremacy of life after death does not mean that the earthly life is valueless and adversary to mankind. Islam only discourages absolute concentration on wealth. It suggests that man will run earthly activities but never will forget his Lord and the life after death. Man will govern his earthly deeds in accordance with his Lord's commands by following the Holy Quran and the sunnah (the way) of the prophet Muhammad (PBUH). The Quranic indication regarding earning wealth, leading earthly life is reflected in the following verse. Allah said:

But seek, with (the wealth) which God has bestowed on thee, the home of the hereafter nor forget thy portion in this world: but do thou good, as God has b een good to thee, and seek not (occasions for) mischief in the land: for God loves not those who do mischief in the land. (Al Quran, 28:77)
There are some indications in aforementioned verse. Firstly, whatever wealth man does possess has been given by Allah. Man cannot own wealth without the grace of Allah. Secondly, he should use his wealth for the sake of the life after death. His wealth should be used in such a way so that his ultimate purpose of the life after death will be realized. Thirdly, man should not forget his portion of wealth in this world. He will endeavour wholeheartedly for legitimate needs of this world. It implies that he cannot lead an idle life. He has to adopt a profession for his livelihood. Fourthly, man is commanded to do the good for others as Allah has bestowed wealth upon him. He will extend his support for others as much as he can by using his wealth. Finally, man has to keep in his mind that by no means he will let his wealth to use in producing collective ills or spreading disorder in the earth. His wealth will be used for the well-being of mankind, not for enhancing harm to society.

What follows from the above discussion is that whatever wealth man does achieve through business is not his absolute property. He is obliged to spend his wealth according to the command of his Lord. It is important to note here that the Islamic standpoint on the question of property is distinguished from both the capitalist and socialist points of view. Unlike capitalism, Islam gives man conditional, not absolute right over his wealth, and does not allow him to spend it as he likes. Unlike socialism, Islam gives man personal right over his wealth, and allows him to spend it for legitimate needs whenever he wants. He needs not to wait for the state to meet his needs. In fact, according to Islam wealth is a trust to a man. Allah, his Lord, wants to see and examine who is good and righteous in using his wealth.

From the Islamic point of view, the purpose of business not only to earn livelihood, but also to realize his ultimate goal 
of life. If he does it according to the command of his Lord, he would be considered to be successful person and the purpose of his business will be a service for the betterment of his fellowbeing and the community and won't be harmful for the society.

\section{Basic principles of business in Islam}

As a human being a businessman should remain alert about his dignity and moral sense. He can't do anything what a wicked man or a thief can do. He can't forget complaisance, honesty, kindness, politeness and modesty in every dealing. A businessman, thus, will be a person of high moral integrity. Without moral consideration business may cause extreme exploitation and immense harm to the society. For good dealings and harmless business, the persons who are engaged in commerce should abide by some basic principles. Islam has provided several principles that are given below:

\subsection{Intention or good will}

Intention is very important behind every act or deed according to Islam. Good intention or good will produces good effects while bad intention or ill will brings forth bad consequences. So, intention determines the merit or demerit of action. There is a very famous tradition of the great prophet Muhammad (PBUH) that says, "Surely, the reward of deeds depends on the intentions and every person will receive reward according to what he has intended." (Imam Bukhari. vol. 1, Hadith no.1) Intention is a mental process. So, it is not easy to identify whether it is good or not. However, manifestation of behaviour and activities refer to the fact that lies behind it. We can guess what kind of planning and scheme someone is making by looking at one's behaviour and activities.

A businessman, first of all, must have this good intention or good will. This intention will motivate him to good acts, valid transaction and sound dealings. If a businessman has ill intention he must adopt ill means in every step of his business.

\subsection{Awareness about halal (lawful) earning}

Business is a very important means of livelihood. So, it is necessary for a businessman to acquire knowledge about lawful and unlawful business. Halal (lawful) earning will make his good fortune for the life here and hereafter, while haram (unlawful) earning will make him shameful and ruinous. According to Islamic tradition,"seeking of knowledge is incumbent on every Muslim." (Imam Ibn-e-Majah, vol. 1, Hadith no. 224) So, in order to benefit from business one should have the correct knowledge of legitimate business. At the same time, he should always remain conscious about halal earning for the betterment of himself as well as of his society.

\subsection{Truthfulness}

Truthfulness is very necessary in every good dealing and relationship. If there is no truthfulness, deception and fraudulence must exist. If one does not remain honest in three steps of business, i.e., production, distribution and the auxiliaries, products and services won't be good in terms of quality.

Every Muslim must be truthful in every matter. He can't cheat anyone. He can't serve inferior stuff after showing specimen of good quality stuff. He can't give less weight than agreed upon. Every Muslim is asked to speak truth. Allah said, "O ye who believe! Fear God, and (always) say a word directed to the Right." (Al Quran, 33:70) "Grievously odious is it in the sight of God that ye say that which ye do not." (Al Quran, 61:3) 


\subsection{Trustworthiness}

Trustworthiness is an essential quality of human being, without which peace and balance cannot exist in a society. A businessman should be aware of trustworthiness and maintain it in every step of his business, since it is the greatest asset for business. It extends reputation of an enterprise.

Earning others' trust may take a long time, but it can be destroyed in a few minutes unless one is not careful about dealings. So, all actions and decisions must be made in a business properly. An entrepreneur can achieve trust by maintaining honesty, integrity and fairness. He can not cheat, betray anyone and adopt wrong means. A Muslim strictly asked to maintain trust and not to betray anyone. (Vide, Al Quran, 4:58, 8:27, 2:283)

\subsection{Sincerity}

Sincerity means doing something cordially with purity of heart. It results in more efficiency as well as a high degree of productivity. It prompts a man to do his duty in the best way, to struggle hard and bear all the troubles.

Sincerity is very much related to business. The principle of sincerity can preserve the interests of all concerned people or groups. Sincerity is free from all kinds of deception, fraudulence, falsehood and outwardness. In case of religious people, especially Muslims, it is very much effective. A Muslim considers all things from the viewpoint of his faith, intention and so forth. A Muslim, a person having trust in Allah, in life after death, in resurrection, in the Day of Judgment etc. works with utmost sincerity for the pleasure of his Master. He struggles and strives sincerely in the cause of Allah to the best of his capability. So, there is no scope of adopting ill means for a true Muslim.

\subsection{Justice}

Justice is very important for business. Literally it means rightness, equity, impartiality, awarding of what is due etc. It is related to human dealings with others. When conflict or claim arises between two or more persons about rights, due deserts or proper behaviour, then whatever conduct be done, that will be either justice or injustice. It means that the concept of justice and injustice refer to the actions of individuals or institution with others. A businessman must ensure justice with concerned ones; otherwise disorder and disturbance will spread among them as well as in society.

\section{All exchangeable things are not subject to business}

Unlike conventional business, Islam holds the view that all exchangeable things cannot be subject to business. According to Islam, humanity, i.e. human purity, human protection, welfare, is most important than profit-making. Impure, unclean, harmful and unlawful things cannot be matter of business. Things that are not allowed for business are discussed as follows with their reasons behind it.

\subsection{Impure things are not subject to business}

It is clear that an unclean and impure thing cannot make other clean and pure. Islam does not permit impure, dirty and harmful things for buying and selling. Islam prohibits trading in intoxicants, living off prostitution, trading in stolen goods etc. Prophet Muhammad (PBUH) says that Allah and his prophet have made haram (unlawful) buying wine, dead animal, swine and idols (Al-Tabrizi, 241). Allah said in the Holy Quran, "O ye who believe! Intoxicants and gambling, (dedication of) stones, and (divination by) arrows, are an abomination, - of Satan's handiwork: Eschew such (abomination), that ye may prosper." (Al Quran, 5:93) In 
another place He said, "He hath only forbidden you dead meat, and blood, and the flesh of swine, and that on which and other name hath been invoked besides that of God." (Ibid, 2:173) Here the Quranic verses and Hadith describe the prohibition of eight things: (1) drinking, (2) gambling, (3) idolatry, (4) divining arrows, (5) dead animal, (6) blood, (7) the flesh of swine and (8) animal that has been sacrificed in the name of anyone other than Allah. All these acts are impure. Producing and selling them are unlawful. We will discuss here some items of them and the reasons underlying their unlawfulness.

\subsubsection{Drinking or intoxication}

It is widely known that drinking is very harmful for body. It causes many diseases including various types of cancer. It harms not only a particular part of a body, but it damages the body as a whole (like brain, liver, stomach, breasts, pancreas, bones, heart, central nervous system etc.). It reduces coordination, impairs memory and loses consciousness.

Apart from bodily damages, it causes different mental disorders, like depression, anxiety, violent behaviour etc. Due to the effect of alcohol, a man loses his rationality and conscience. He cannot distinguish between right and wrong, good and bad. Drinking, thus, causes to harm an individual, a family as well as society. So, Islam has correctly prohibited producing, selling and buying it. Drug is his only one desired thing. He becomes lunatic for drug. He can do everything for drug. He needs a big amount of money for the fulfillment of his intoxication. For money he adopts different ill means, like stealing, deception, fraudulence etc. Sometimes he oppresses the people of his surroundings.

\subsubsection{Dead animal}

Al Quran says that maitat - the dead animal - is haram (unlawful). Maitat means carrion, i.e. the flesh of such animal that dies of itself. The flesh of that animal which has not been slaughtered in the manner prescribed by Islamic law is forbidden to eat, buy and sell. An animal may die of various reasons. It may be strangled to death, may be beaten to death, may be died through a fall from a height, may be smitten to death with another animal's horn, may be died of sickness or any disease, may be died as food of other animal. All kinds of carrion are forbidden by Islam. The wisdom underlying behind this is as follows:

The main reason for forbidding carrion is its impurity. The animal which is not slaughtered in Islamic method, rather which is died of any reason, its meat is harmful for health. The blood of that animal gets stopped in body. As a result, the meat becomes very quickly perverted. In addition, in blocked blood germs remain alive, even that germs are not perished by burning. On the other hand, the animal which is slaughtered in Islamic manner, the total liquid blood gets out of body. The meat, thus, becomes pure. It is hygienic and not harmful for health. The question remains: what about hair and fat of dead animal? The answer is that the eatable parts of dead animal are forbidden for selling and buying while the uneatable parts are legitimate in buying and selling.

\subsubsection{The blood}

The above mentioned Quranic verse proclaims that the blood is forbidden. Here blood means the flowing blood. It bears various kinds of germ and ferocity, so it is very harmful for eating. Apart from this, it is impure. Every impure thing is forbidden in Islam. So selling, buying and all income earned from it is forbidden. What about blood transfusion? Some have 
permitted the use of blood on medical grounds. The transfer of human blood to another body is not permissible under normal conditions, but in compulsive conditions i.e. the life saving conditions doing so is permissible. (Shafi,430) For life saving, blood can be collected from relatives, from donor at the free of cost, from Blood Bank or any other legitimate sources.

\subsubsection{The flesh of swine}

The Holy Quran has declared the flesh of pig as haram (unlawful) 5 times in different verses. Swine is a dirty animal. It lives on offal. Its body is a container of infectious diseases. Moreover, its flesh belongs much fat than muscle building ingredients. It carries such germ which cannot even be destroyed by burning. So, eating pork may cause of several diseases.

It should also be mentioned here that eating something that is not permitted by Islam does not affect only body, but it has far-reaching impact upon human mind and nature. We also find such affects among animals. Blood and flesh-eating animals are much crueler than non-flesh eating animals. The nature of the tiger, the lion, the bear are different from that of the cow, the buffalo and the goat. The first three are flesh-eating animals. Therefore, it would not be an exaggeration to say that eating materials influence over the nature of eater. Islam, thus, on the one hand keeps human body disease-free by forbidding filthy and disease-prone things like, dead meat, blood and pork. On the other hand, Islam shows the way to remain pure by forbidding those cruel animal's meat as well as impure things.

\subsection{Harmful things are not subject to business}

Goods which are not be useful for humanity are not legitimate to sell or buy according to Islam. For example, snake, rat, hornet, worms and insects etc. are not to be sold or bought.
However, dogs for guarding, elephants for transporting and those animals whose skins are used for making useful goods are legitimate for selling and buying. Similarly, there are some animals (it is immaterial whether eating their meat is lawful or not), they are very beautiful to look at, like peacock, and some animals have sweet sound, i.e. those animals which have aesthetic value are allowed to sell or buy in Islam.

\subsection{Things which are not virtually transferable are not subject to business}

Things that are not in a position to deliver can not be matter of selling or buying. Fetus in a womb, yet unborn or unripe fruits in tree or garden and uncut corps in the field cannot be sold or bought. Similarly, the bird in the air, the fish in the water cannot be the object of selling or buying.

\subsection{Things which are unknown or indefinite can not be subject to business}

Both goods and prices must be known and fixed according to Islam. In case of unknown and unfixed price of goods for selling and buying will not be valid; for example, if a diver said, I would dip into water this time, and whatever I would catch, I would give you for this fixed amount (like one thousand, two thousand etc.) of money. In this case price was fixed earlier but goods were indefinite and unknown. This type of business is not allowed in Islam as valid.

\section{Why some things are not subject to business}

Things which are not subject to business are of three categories:

6.1. Things that are by nature impure and harmful.

6.2. Things that are not by nature impure and harmful, they are good in nature but they become corrupted for using unfair means.

6.3. Things which dealings are not transparent. 
These three categories have been discussed below:

6.1. We have previously seen that there are some things which are essentially impure, germful, diseased, poisonous and filthy. This category includes dead animal, blood which flows, the swine, wine, etc. These impure things cannot make man pure and healthy. These things are not only harmful for human body but their ill effects hinder the mental development of man. Where physical and mental development disrupts, there spiritual excellence cannot be attained. Islam abhors these items and proclaims as haram (totally forbidden). Islam gives preference of spirituality to body and mind. But it does not ignore the last two. Forbidding these items Islam has taken an effective measure for tripartite development of body, mind and spirit.

6.2. There are some things which are essentially pure and good. Things which by themselves are not forbidden for buying or selling, but they have characterized in different names due to unfair means, e.g. stolen things, smuggled things, things owned by others (like husband's property or wife's property) without permission of the owner, are not considered as valid for selling and buying. Incomes from this kind of things are haram. Moreover, in these dealings, one is deprived from his right. Secondly, the seller or buyer of stolen or smuggled things is extending their hands in an illicit deed. Thirdly, there are possibilities to dismiss mutual trust, good relation and fellowfeeling. Islam, thus, has attempted to save society from malpractice and unwarranted meddling by forbidding selling and buying things that one earns by unfair means and not by possession.

6.3. Some businessmen may adopt such process in which goods, price and delivery are unknown, indefinite, unclear and not transparent as we have seen above. In these cases deception, fraudulence, roguery may take place. Undoubtedly, in it one party loses and another gains. As a result, seller-buyer will be involved in quarrel. Suppose a situation, one sold his fruits in the garden which are yet not ripen. After some days fruits became ruined by natural cause. Now the seller said, I have sold these, so I am not liable for this and I will not be loser. On the other hand, the buyer said, I did not get fruits at all, so I would not be liable for this. For these reasons, Islam has forbidden the selling and buying of unknown, indefinite goods which delivery is doubtful.

\section{The ethics of consumer protection}

Consumers are the main stakeholder of business. However, they are often deprived and deceived by means of substandard products, misinformation, increasing prices, creating artificial crises and so on. They have some rights. To discuss the ways of the protection of their rights is an important issue of business ethics. Islam stresses on the protection of their rights as explained below:

\subsection{The right to get quality products and services}

Consumers have rights to get quality products, goods and services from producer and service provider. The customers and consumers have the right to get standard and appropriate goods, as Allah said: "Nor withhold from the people the things that are their due; commit not evil in the land with intent to do mischief." (Al Quran, 11:85). Selling commodities with less than the accurate weight and measurement is a very well known way of cheating in business. Nowadays it has taken various forms like adulteration, harmful chemical mixed production etc. Islam has strictly prohibited such dealing. Allah said, "Woe to those that deal in fraud. Those who, when they have to receive by measure from men, exact full measure. But when they have to give by measure or weight to men, give less 
than due." (Ibid, 83:1-3, vide, 11:85, 17:35, 55:7-9) These types of businessmen according to Islamic shari'ah, will be punished in earthly life as well as in life after death.

\subsection{The right to be informed}

The customers and consumers have the right to know all about the products. So, goods or service providers should disclose the maximum possible information. If there is any defect, the buyer should be informed about that and then it is up to buyer to accept to buy or not. Hiding any known defect in an item offered for sale is a matter of deception and it causes loss and harm for buyer. Sometimes it may lead to quarrel with each other and may make disorder in society. Islam has strongly forbidden it. Allah said, "Nor withhold from the people the things that are their due: And do no mischief on the earth after it has been set in order." (Ibid, 7:85, 11:85)

\subsection{The right to healthy environment}

The healthy environment is very important for the sustainable living. Environment can be polluted in many ways. Industrial plants are one of them. Manufacturing process may cause a great harm for environment. Industrial smoke and waste are health hazard. But their proper management will keep the environment safe. Industrialist, manufacturer and businessmen are always not aware and often careless about the healthy environment because of their profit-maximizing target. Businessman will run business but he cannot hamper consumer's healthy environment right making various kinds of pollution.

Islam stresses on the protection of environment. Allah has created all necessary things for the equilibrium of environment. Allah said: "And the earth we have spread out (like a carpet); set thereon mountains firm and immovable; and produced therein all kinds of things in due balance." (Ibid, 15:19, vide, 78:14-16, 35:22-28, 2:195. 16:80-81) Man has the role towards the environment by making himself responsible of his surroundings. Man destroys his environment by abusing it. He cuts tree, hills, fills up river and canals. As a result, nature becomes adverse for men. Allah said, "Mischief has appeared on land and sea because of (the meed) that the hands of men have earned." (Ibid, 30: 41) So producer, manufacturer and business man should keep it their mind that environment can never be destroyed or polluted by their initiatives. According to Islam, keeping environment clean is a part of faith.

\subsection{The right not to be deceived}

Customer will be served properly in all respects. He will not be deceived in any way. Telling lie, bearing false witness, hypocrisy, delivering adulterated goods, misleading representation on utility of products, false and exaggerate advertising, these are all means of cheating. Islam has abhorred and strictly prohibited all these kinds of malpractices. Telling lie, giving false witness, hypocrisy, cheating etc. are considered great sin in Islam. Prophet Muhammad (PBUH) said, "Refrain from taking more oath in business, it may get some profits, but the prosperity will vanish from their trade." (al-Tabrizi, 243)

\subsection{The right to legal aid}

Consumer has the right to demand redress. He can complain to authorities concerned like association of manufacturers, association of traders, government etc. Concerned authorities will take necessary measure. According to Islam, a businessman who commits sin, crime in his dealings in any means, will be brought to book based on shari'ah in the worldly life and he will also be punished in the life hereafter. Allah said, 
The punishment of those who wage war against God and His Apostle, and strive with might and main for mischief through the land is: execution, or crucifixion, or the cutting off of hands and feet from opposite sides, or exile from the land: that is their disgrace in this world, and a heavy punishment is theirs in the Hereafter. (al Quran, 5:36)

\section{Hoarding}

Hoarding is a very bad practice in business. It exploits the customers. Hoarding means stocking essential commodities to create an artificial scarcity for the purpose of pushing up the prices. The lust for money and the desire for becoming overnight richer lead a businessman to hoard essential commodities with a view to sell the same at manifold prices. Islam has prohibited this strictly. The prophet Muhammad (PBUH) said, "The one who brings food to the market, Allah will grace him, provide well, while the one who hoards is cursed by Allah." (al-Tabrizi, 251) The reason behind the prohibition of hoarding is to keep the essential commodities available in the open market so that customers and consumers can get that with fair prices. On the other hand, Islam wants to prevent covetousness, profiteering, corruption, dishonesty etc. Above all, Islam emphasises on the protection of common people's interest and not to harm them any way.

\section{Obligations to employee and employer in Islam}

According to Islam all men are equal in respect of creation of Allah. They all are from the same source. But one is superior to others in terms of knowledge and responsibility. None is here totally self-dependant. Everyone is to come in contact with each other as one set requires the services of the other and vice versa. However, everyone has some obligations to others. Islam suggests fair, just and benevolent treatment of each. Here we would like to draw attention to some points that are related to the obligations of employer to employees and vice versa.

\subsection{Obligations of employers to employees}

\subsubsection{Fair recruitment practices}

First of all, a business entrepreneur has a moral obligation to recruit all levels of employees on fair and transparent basis. According to Islam, there is no scope of discriminations, nepotism, corruption and bribery in recruitment process. Among the job seekers, the best person has the right to obtain desired post. An honest businessman cannot deprive the deserving persons and do injustice. Allah said, "God doth command you to render back your trusts to those to whom they are due; and when ye judge between man and man, that ye judge with justice." (Al Quran, 4:58)

\subsubsection{Fair treatment of workers}

Man is the most excellent of the creatures. So, workers or any man should not be treated as machines or tools, but as human beings. Employers should provide equal opportunities to all employees irrespective of their race, caste, gender, religion etc. Islam emphasises on fair wages, good working environment and brotherly treatment of the workers. The great prophet Muhammad (PBUH) said, "Pay the worker his wages before his sweat dries." (Imam Ibn-e-Majah, vol. 3, Hadith no. 2443) Further he said, "Allah said, I will be a plaintiff to three types of people on the Day of Judgment: .... One who employs a labourer and takes full work from him but does not pay him due wages." (Imam Bukhari, vol.3, Hadith no. 2270)

\subsubsection{To give share of profits}

Workers produce wealth, make profit. They work hard. So, only wages are not enough for them. Profits should be 
distributed among them. If not so, wealth will be accumulated in one hand i.e. all profits will go to owner's possession. Islam does not allow it. Allah said, "It [wealth] may not (merely) make a circuit between the wealthy among you." (Al Quran, 59:7) Sometimes accumulated wealth may cause exploitation. If profits only go to the possession of investor or capital provider, it makes the rich richer; but the poor (workers, labourer) remains poor. It eventually makes the have and the have not.

Some think that when employer earns big amount or extra profit then employees should be given insentives or additional benefit. It will help employees but it will deprive them from getting share of profits. But we think, not only insentives or bonuses, but they always should be given a certain share of profits. Islam directs us to do so. The prophet Muhammad (PBUH) said:

Allah has made some of your brothers as slaves under your care. So whoever has his brother under his care, then let him feed him from his food, and let him clothe him from his clothes. And do not give him such duty that he can not bear, and if you give him a duty he cannot bear, then assist him with it. (Imam Tirmidhi, vol. 4, Hadith no. 1945)

This hadith makes each worker a brother of his employer.

\subsection{Obligation of employees to employer}

\subsubsection{Professional responsibility}

It is generally expected that an employee will be dedicated to his employer with high standard of professional responsibility. He will be committed to maximize the goal of his employer. He must discharge his duty with integrity and will be respectful to the confidential matter to which he has access.

\subsubsection{Protection of employer's assets}

Employees should keep in their mind that the assets and properties of the employer are a trust on them. They must not abuse and misappropriate the trust. Furthermore, they must not do anything to cheat or deceive the employer directly or indirectly. Similarly, they must neither embezzle the funds nor disclose any secrets of employer to outsiders.

\subsubsection{Considering duty as worship}

An employee must perform his duty not only for the salary but also as ibadah- worship. As an employee he is liable for his work to his employer while as a believer he is liable for his work to his Lord-Allah. If he performs his duties perfectly, he will be rewarded by the Almighty. But willful negligence will be considered as sin. An employee will be asked for his responsibility. The prophet Muhammad (PBUH) said: "All are custodians and are responsible for their charges." (Imam Bukhari, vol. 2, Hadith no. 18)

\section{Corporate Social Responsibility of Business}

Business is not only for profit-making initiative but businessperson has important responsibility to his surrounding people, community, country and the mankind as well. This responsibility is called corporate social responsibility (CSR). What is CSR? The World Business Council For Sustainable Development defines it as:

Corporate social responsibility is the continuing commitment by business to behave ethically and contribute to economic development while improving the quality of life of the workforce and their families as well as of the local community and society at large. (Fernando, A.C., 218)

First of all, the social responsibility of businessperson is ethical. They should not do anything that is ethically wrong. 
Their dealings and transaction should be accomplished abiding by the norms of morality and transparency. At the same time, it is their responsibility to provide quality goods and commodities, i.e. they are morally bound to provide things that are not harmful for customers and consumers as well as society. Islam has strictly prohibited any fraudulence in dealings and proclaimed haram - unlawful of harmful things' selling and buying like wine, flesh of swine, dead meat etc. According to Islam, a perpetrator will be brought to book in the conventional court as well as before Allah in the Day of Judgment. (Al Quran, 5:33, 2:85) The prophet Muhammad (PBUH) said: "No foot of a servant of Allah [on the resurrection day] will move before being asked about four things: ... his wealth and how he earned it and on what he spent it....(Imam Tirmidhi, vol. 2, Hadith no., 2416)

Secondly, business person has another important responsibility to contribute to the economic development as much as he can. It is his responsibility to employ unemployed persons of his society. He has to help financially the poor, destitute and insolvent people of his community. Islam has done mandatory social responsibility for a businessman by declaring zakat (regular charity) in business commodities. A Muslim businessperson is bound to pay zakat to the poor every year for his business commodities. Moreover Al Quran has repeatedly stressed on voluntary charity. Allah said:

It is not righteousness that ye turn your faces towards East or West; But it is righteousness to believe in God, and the last day....To spend of your substance, out of love for Him, for your kin, for orphans, for the needy, for the wayfarer, for those who ask, and for the ransom of slaves; To be steadfast in prayer, and practice regular charity [zakat]. (Al Quran, 2:177)
Thirdly, another responsibility of businessman is to work for the betterment and welfare of his subordinates and their families and local community as well. He will be with them in their every weal and woe. He will help them in their every necessity. Islam does not think their relationship as owner and servant, boss and dependent but Islam presents their relationship as brethren and oneness. Allah said: "The believers are but a single brotherhood." (Ibid, 49:10) If a businessman does not feel his workers or his community sympathetically, he is not a true Muslim. The prophet Muhammad (PBUH) said, "None of you truly believes until he loves for his brother" or he said, "for his neighbour, what he loves for himself." (Imam Ibn-e-Majah, vol. 1, Hadith no. 66.) Further he said, "Nobody will be considered to be a true believer unless he likes for his brother the same thing which he likes for himself." (Imam Bukhari, vol. 1, Hadith no.13)

\section{Conclusion}

Islamic business ethics presents an extensive but clear principles, rules and regulations concerning business. It always reminds a businessman that the business is not only for profitmaking, but also an ibadah-worship. If one obeys the rules of business provided by Islam one performs not only one's professional duty but also divine duty. If he does his acts morally he will be rewarded in the Day of Judgment, otherwise he will be punished. Islam puts up the concept of two lives, worldly and other-worldly.

Islamic business ethics is humanistic in terms of attitude, nature, aim and spirit. Its main purpose is to assist one to fulfill one's ultimate goal, not to maximize profit. It strictly prohibits producing, selling and buying of those goods that are things in themselves harmful for mankind like wine, pork, blood, etc. Not only that, it prohibits selling of legal things for illegal use, 
e.g. weapons, drugs, etc. Grapes are lawful fruits, its selling and buying are also lawful. But Islam prohibits its selling to one who makes professionally wine by it. Similarly, selling weapons is not permissible to one who engages in illegal or unjust war. (Sabeq, 147)

Any immorality, according to Islam, is sin. This concept is very important for a business man. It leads him to avoid any unfairmeans. Islamic business ethics also prescribes that earning by unfairmeans is haram, and one's ibdah will not be accepted, if one adopts haram earnings. Therefore, Islamic business ethics teaches that a businessman should make him clean, pure and moral for his spiritual grounds as well as salvation.

In fine, we can sum up from above discussions that the Islamic business ethics rightly shows a businessperson as well as an organisation proper principles of morality. These principles are able to lead business activities on right track. Accordingly, this ethics can protect business from decadence of morality and humanity.

\section{References}

Ali, A. Yusuf, (1983), The Holy Quran: Text, Translation and Commentary, USA: Amana Corp.

Al Tabrizi, Shaikh Wali al-Din Muhammad Bin Abdullah al-Khatib al Umari, (N.D.),

Mishkatul Masabih, India : New Delhi ; M Bashir \& Sons.

Fernando, A.C., (repr.2014), Business Ethics: An Indian perspective, India: New

Delhi; Dorling Kindesley pvt. ltd..

Ibn Majah, Muhammad Bin Yazeed al Qazwini, (2007), Sunan Ibn Majah, trans. al
Khattab, Nasiruddin, Saudi Arabia: Riyadh: Darussalam Publishers $\&$ Distributors.

Imam Bukhari, Muhammad bin Isma'il bin Al Mughirah, (1997), Sahih al Bukhari, (Arabic-English), trans. Khan, Muhammad Muhsin, Saudi Arabia: Riyadh : Darussalam Publishers \& Distributors.

Imam Tirmidhi, Hafiz Abu 'Isa Muhammad Ibn 'Eisa, (2007), Jami“ At Tirmidhi,

trans., Khaliyl, Abu, Saudi Arabia: Riyadh: Darussalam Publishers $\&$ Distributors.

Kant, Immanuel, (1962) Fundamental Principles of The Metaphysic of Ethics, (1 ${ }^{\text {Oth }}$ ed.), trans. Abbott, T.K., London: Longmans.

Satris, Stephen, (ed.), (1988), Taking sides: Clashing views of controversial Moral Issues, U.S.A. : The Dushkim publishing Group, Inc.

Shafi, Mufti Muhammad, Ma'ariful Quran, (N.D.), trans., Muhammad Hasan Askari \& Muhammad Shamim, India : New Delhi : Farid Book Depot (P) Ltd.

Sabeq, Syed, (1983), Fiqhus Sunnah, (4 ${ }^{\text {th }}$ ed.), vol. 3, Lebanon: Bairut; Darul Fiqh. 